\section{Australian Journal of \\ Crop Science}

AJCS 14(07):1202-1208 (2020)

doi: 10.21475/ajcs.20.14.07.p2630

\title{
Effect of reduced spacing on relationship of physiological, morphological and productive traits of corn yield
}

\author{
Luan de Oliveira Nascimento ${ }^{1 *}$, Josimar Batista Ferreira ${ }^{1}$, Gleisson de Oliveira Nascimento ${ }^{2}$, Vanderley \\ Borges dos Santos ${ }^{1}$, Clemeson Silva de Souza ${ }^{1}$, Antonia Fabiana Barros de Lima ${ }^{1}$, Francisco lan de Oliveira \\ Nascimento ${ }^{2}$
}

\author{
${ }^{1}$ Center for Biological and Natural Sciences, Federal University of Acre, Rio Branco CEP: 69920-900, Acre, \\ Brazil \\ ${ }^{2}$ Multidisciplinary Center, Federal University of Acre, Cruzeiro do Sul, CEP: 69980-000, Acre, Brazil
}

\author{
*Corresponding author: luan17czs@yahoo.com.br
}

\section{Abstract}

Increasing corn grain production without devastating new forest areas is a viable alternative to controlling deforestation. However, increasing plant density in the area may alter plant morphophysiological and productive traits. The objective of this study was to characterize relationships between physiological, morphological and yield traits of corn plants, as well as the cause, effect and relationship of the traits on grain yield. The experiment was carried out in randomized complete block design with four replications. The corn hybrids (2B655PW, AG7088PRO3 and P4285YHR) were grown with row spacing of $40 \mathrm{~cm}, 60 \mathrm{~cm}, 80 \mathrm{~cm}, 95 \mathrm{~cm}$. The evaluated traits physiological were: net photosynthesis $\left(P_{N}\right)$, stomatal conductance $\left(G_{s}\right)$, intercellular concentration of $\mathrm{CO}_{2}(\mathrm{Ci})$, leaf transpiration (E), water use efficiency (WUE) and carboxylation efficiency (CE). The morphological were: plant height (PH) and ear insertion height $(\mathrm{EIH})$, stem diameter (SD), and leaf area (LA) and the productive traits were the total number of ear per hectare (NE), number of grains per ear (NGE), grain mass per ear (GME), 100 grain weight (100GW) and grain yield (GY). The characteristics of maize hybrids cultivated in environment with reduced spacing $(40 \mathrm{~cm}, 60 \mathrm{~cm}, 80 \mathrm{~cm}, 95 \mathrm{~cm})$ of the $2016 / 2017$ crop were investigated through the multicollinearity path analysis. The physiological, morphological and productive traits are considered sources of variation of cause and effect of corn yield in reduced spaced. This traits are essential for observations in maize breeding programs to obtain high yielding varieties in reduced spacing. In conclusion, the physiological $\left(\mathrm{P}_{\mathrm{N}}, \mathrm{CE}, \mathrm{WUE}, \mathrm{Ci}, \mathrm{Gs}\right)$, morphological $(\mathrm{EIH}, \mathrm{SD}, \mathrm{LA})$ and productive (NE, GME) traits provide gains in maize grain yield via indirect selection when the crop is subjected to $40 \mathrm{~cm}$ row spacing.

Keywords: Path Analysis; biometry; correlations; Zea mays.

Abbreviations: $\mathrm{P}_{\mathrm{N} \_}$net photosynthesis; $\mathrm{G}_{\mathrm{s}_{-}}$stomatal conductance; $\mathrm{Ci}$ intercellular concentration of $\mathrm{CO}_{2} ; \mathrm{E}_{-}$leaf transpiration;

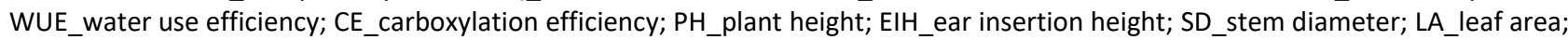
NE_total number of ear per hectare; NGE_number of grains per ear; GME_grain mass per ear; 100GW_100 grain weight; GY_grain yield.

\section{Introduction}

Maize crop (Zea mays L.) has significant importance in the world market, being crucial for global food security (Anjum et al., 2016). Meeting the needs of the consumer market requires large extensions of agricultural lands. However, environmental concerns about preserving native forests have led to greater control of this crops expansion. Thus, increasing grain yield by techniques that optimize cultivation in smaller areas is of interest to modern science (Saath and Fachinello, 2018). The growing need for grain leads to continuous research focused on genetic improvement and management technologies, aiming to increase productivity in cropping systems (Nardino et al. 2016). However, the selection of superior genotypes is quite complex because grain yield characteristics have quantitative action on genes and must be considered simultaneously in grain yield (Ribeiro et al., 2014). In maize breeding programs, one of the basic objectives is to obtain genotypes with higher productive capacity (Olivoto et al., 2018). This can be achieved with management practices such as reducing row spacing capable of increasing maize productivity in small agricultural land (Nascimento et al., 2019). In contrast, with variations in row spacing, excessive amounts of plants per area may result in competition for survival components such as light, water and nutrients, interfering with corn physiology, growth and development (Pellizzaro et al., 2019). Since corn crop yield is a function of the interaction of environment with genotype, the expression and association of physiological, morphological and productive components 
can expose the contribution of each trait to grain yield (Vian et al., 2016; Yin et al., 2018). Thus, the knowledge of the degree of this association by correlation study allows identifying traits that can be used in indirect selection for yield (Santos et al., 2018a), as well as modifying the selection dynamics in maize breeding programs (Carvalho et al., 2018).

Among the correlation techniques, the path analysis has been used in studies to evaluate the direct and indirect effects of phenological, morphological and productive characters on grain yield in modern agriculture (Toebe and Cargnelutti Filho, 2013; Milander et al., 2017; Guimarães et al., 2019). In addition to the components related to productivity, it is interesting to know the processes related to plant growth and development associated with photosynthetic activity to expose physiological performance in certain situations (Santos et al., 2018b).

Despite the efforts, it is noteworthy that information on the direct and indirect influence of reduced spacing on physiological characteristics, growth and yield on grain yield of cultivated corn remains unknown. Therefore, the objective of this research was to determine the association of physiological, morphological and productive components, as well as the cause and effect relationship on corn grain yield under reduced spacing by trajectory analysis.

\section{Results and discussion}

\section{Phenotypic correlation}

The physiological, morphological and productive components of corn presented positive and negative correlation on grain yield, which explains the variation of corn grain production in environments with reduced spacing (Table 1). In general, phenotypic correlation is used to verify the linear association between two directly observed characteristics (You et al., 2016). Thus, the positive effect between the traits shows that the increases are proportional, while the negative coefficients indicate inversely proportional associations (Alves and Cargnelutti Filho, 2017).

The characteristics of high positive correlation with GY were $\mathrm{SD}>\mathrm{EIH}>\mathrm{GME}>\mathrm{CE}>\mathrm{PH}>\mathrm{WUE}$, with greater total effect, respectively. On the other hand, the characteristics $L A>N E$ $>\mathrm{Ci}>\mathrm{Gs}>\mathrm{E}$, presented a high negative coefficient on GY. The $P_{N}, N G E$ and $100 \mathrm{GW}$ showed no phenotypic association in $\mathrm{GY}$ of the hybrids cultivated of $95 \mathrm{~cm}$ and $40 \mathrm{~cm}$ row spacing. Probably, the effect of additional factor acted on this relationship and prevented any association between these characters.

Because the components are interrelated and the plant develops in environments with high plant density, phenotypic correlations may not provide clear importance of each component in determining grain yield, as the correlation between two traits may be due to a third factor that is environmental or genetic (Xu et al., 2017). Therefore, because corn grain yield is a quantitative trait, path analysis can more accurately assess the true cause and effect relationships between the characters studied simultaneously on grain yield (Reddy and Jabeen, 2016).

\section{The direct and indirect effects of physiological traits on GY}

Path analysis under multicollinearity with the addition of the constant $k=0.05$ was efficient to estimate the direct and indirect effects of physiological traits on GY (Table 2). The value of the coefficient of determination $(R 2=0.98)$ and the low effect of the residual variable $(U=0.15)$ showed that $P_{N}$, $\mathrm{Ci}, \mathrm{Gs}, \mathrm{E}, \mathrm{CE}$ and WUE are $98 \%$ of the total variation of yield grains of hybrids cultivated of $95 \mathrm{~cm}$ and $40 \mathrm{~cm}$ row spacing. According to Zuffo et al. (2018) the characteristics that present direct and indirect effect trail coefficient below the residual variable do not influence the main variable. Thus, the physiological components with the greatest positive direct effect on grain yield were $P_{N}(r=0.48)$, CE $(r=0.34)$ and WUE $(r=0.19)$, while $\mathrm{Ci}(r=-0.27)$ and $\mathrm{Gs}(r=-0.17)$ had the greatest negative direct effect on the main variable (GY). Analyzing the indirect effect found that leaf transpiration $(E)$ via $P_{N}(r=0.29)$ and $C E(r=-0.31)$ were the traits with the highest positive and negative magnitude on grain yield, respectively. This shows the importance of these characteristics in the cause and effect relationship of grain yield. The main reason that maize has high physiological ability to intercept sunlight and convert $\mathrm{CO}_{2}$ into assimilates, especially carbohydrates (Mansfield and Mumm, 2014) is the efficiency of radiant energy conversion in dry matter due to the $\mathrm{C} 4$ photosynthetic process, in which carbon dioxide is concentrated in the leaf vascular sheath cells and the carbohydrates are translocated to regions where they will be stored, providing higher grain yield (Renato et al., 2018).

These results suggest that high liquid photosynthesis, as well as carboxylation efficiency and water use efficiency can directly promote increase in grain yield, while $\mathrm{CO}_{2}$ concentration and stomatal conductance present low magnitude. Such observation corroborates with the reports of Santos et al. (2018b), when they pointed out that the physiological trits are interrelated with the photosynthetic efficiency, so that high photosynthesis rates combined with low internal $\mathrm{CO}_{2}$ concentrations provide greater carboxylation efficiency, and consequently, increases the production of photoassimilates.

\section{The direct and indirect effects of morphological traits on GY}

The analysis of the path under multicolinarity showed good adjustment of the constant $\mathrm{k}(0.05)$ for the morphological traits. The cause and effect coefficients of GY, presented coefficient of determination of R2 $=0.98$ (Table 3 ) and the $U$ effect was 0.14 . Thus, the high percentage of variation observed for grain production can be explained by characteristics of plant and ear height, stem diameter and leaf area.

The ear insertion height (LA) and the stem diameter (SD) showed the greatest positive direct effect. These traits can contribute proportionally to the increase of grain yield, indicating that plants with higher ear insertion height and high stem diameter are likely to increase grain yield. Therefore, high plant density increases competition for light and stimulates apical dominance and increases ear height by decreasing stem diameter. However, modifications are needed where the ratio of plant to ear height is lower and increases the stem diameter, so that the plants do not break and reach higher yield (Leolato et al., 2017). On the other hand, leaf area showed negative direct association on GY ( $r=$ -0.43), indicating that the larger the leaf area, the plant tends to decrease grain yield. Similarly, Mansfield and Mumm (2014), evaluated maize hybrids at different planting densities and observed that leaf area was negatively correlated $(r=-0.62)$ with grain yield. In general, continuous growing maize plants begin to use their nutritional reserves to expand their leaves, which reduces the production of 
Table 1. Phenotypic correlation of physiological, morphological and productive components on grain yield of maize hybrids cultivated in reduced spacing.

\begin{tabular}{lc}
\hline Associated characters & Phenotypic coefficient \\
\hline$P_{N} \times G Y$ & 0.19 \\
Ci $\times$ GY & -0.88 \\
Gs $\times$ GY & -0.80 \\
E x GY & -0.66 \\
CE x GY & 0.92 \\
WUE x GY & 0.83 \\
PH x GY & 0.88 \\
EIH x GY & 0.98 \\
SD x GY & 0.99 \\
LA x GY & -0.99 \\
NE x GY & -0.86 \\
NGE x GY & 0.27 \\
GME x GY & 0.93 \\
$100 G W \times G Y$ & 0.02 \\
\hline
\end{tabular}

Note: $\mathrm{P}_{\mathrm{N}}$ net photosynthesis; $\mathrm{Ci}_{\mathrm{CO}} \mathrm{CO}_{2}$ internal concentration; Gs_stomatal conductance; E_perspiration; $\mathrm{EC}_{-}$Carboxylation efficiency; WUE_water use efficiency; $\mathrm{PH} \_$plant height; ElH_Ear insertion height; SD_stem diameter; LA_leaf area; NE_number of ear; NGE_Number of grains per ear; GME_Grain mass per ear; 100GW_100 grain weight; GY_Grain yield.

Table 2. The phenotypic correlation of physiological components in direct and indirect effect on the dependent trait main grain yield (GY).

\begin{tabular}{|c|c|c|c|}
\hline Characters & \multirow{2}{*}{ Path coeficiente } & Characters & \multirow{2}{*}{ Path coeficiente } \\
\hline $\mathrm{P}_{\mathrm{N}}$ & & $\mathrm{E}$ & \\
\hline Direct effect on GY & 0.48 & Direct effect on GY & -0.04 \\
\hline Indirect effect via Ci & -0.07 & Indirect effect via $\mathrm{P}_{\mathrm{N}}$ & 0.29 \\
\hline Indirect effect via Gs & -0.07 & Indirect effect via $\mathrm{Ci}$ & -0.25 \\
\hline Indirect effect via E & -0.02 & Indirect effect via Gs & -0.17 \\
\hline Indirect effect via CE & -0.06 & Indirect effect via CE & -0.31 \\
\hline Indirect effect via WUE & -0.07 & Indirect effect via WUE & -0.18 \\
\hline Total & 0.19 & Total & -0.66 \\
\hline $\mathrm{Ci}$ & & CE & \\
\hline Direct effect on GY & -0.27 & Direct effect on GY & 0.34 \\
\hline Indirect effect via $\mathrm{P}_{\mathrm{N}}$ & 0.13 & Indirect effect via $P_{N}$ & -0.09 \\
\hline Indirect effect via Gs & -0.17 & Indirect effect via $\mathrm{Ci}$ & 0.27 \\
\hline Indirect effect via E & -0.04 & Indirect effect via Gs & 0.16 \\
\hline Indirect effect via CE & -0.34 & Indirect effect via E & 0.04 \\
\hline Indirect effect via WUE & -0.19 & Indirect effect via WUE & 0.19 \\
\hline Total & -0.88 & Total & 0.92 \\
\hline Gs & & WUE & \\
\hline Direct effect on GY & -0.17 & Direct effect on GY & 0.19 \\
\hline Indirect effect via $\mathrm{P}_{\mathrm{N}}$ & 0.20 & Indirect effect via $\mathrm{P}_{\mathrm{N}}$ & -0.18 \\
\hline Indirect effect via Ci & -0.26 & Indirect effect via $\mathrm{Ci}$ & 0.27 \\
\hline Indirect effect via E & -0.05 & Indirect effect via Gs & 0.17 \\
\hline Indirect effect via CE & -0.33 & Indirect effect via E & 0.04 \\
\hline Indirect effect via WUE & -0.19 & Indirect effect via CE & 0.34 \\
\hline Total & -0.80 & Total & 0.83 \\
\hline Determination coefficient $\left(\mathrm{R}^{2}\right)$ & & & 0.98 \\
\hline K value & & & 0.05 \\
\hline Residual trait (U) & & & 0.15 \\
\hline
\end{tabular}




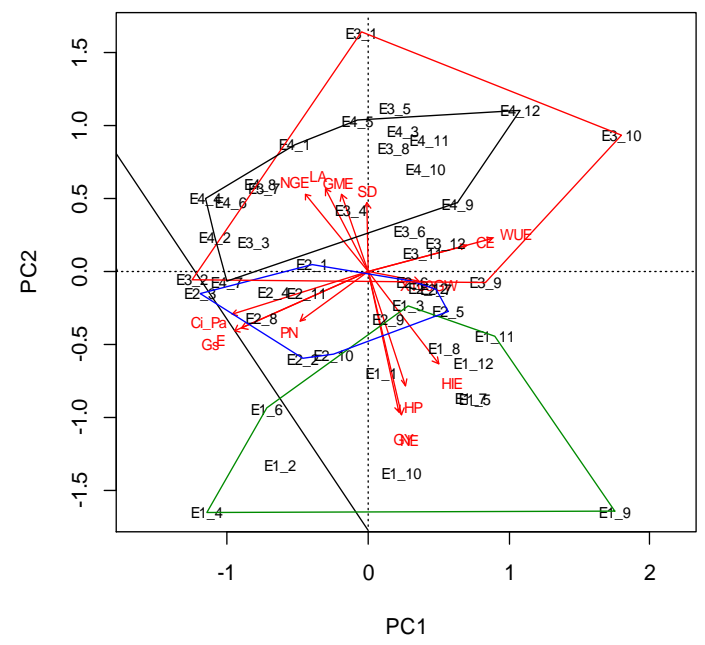

Fig 1. Principal component analysis (PCA) of physiological, morphological and productive traits of hybrid corn in reduced spacing. PN_net photosynthesis; Gs_stomatal conductance; $\mathrm{Ci}$ _intercellular concentration of $\mathrm{CO}_{2}$; E_leaf transpiration; WUE_water use efficiency; CE_carboxylation efficiency; $\mathrm{PH} \_$plant height; EIH_ear insertion height; SD_stem diameter; LA_leaf area; NE_total number of ear; NGE_number of grains per ear; GME_grain mass per ear; $100 \mathrm{GW} \_100$ grain weight; GY_grain yield; E1_40 cm spacing; E2_60 cm spacing; E3_80 cm spacing; E4_95 cm spacing; Green Polygon_40 cm spacing; Blue Polygon_60 cm spacing; Red Polygon_80 cm spacing; Black Polygon_ $95 \mathrm{~cm}$ spacing.

Table 3. The phenotypic correlation of morphological components in direct and indirect effect on trait dependent main grain yield (GY).

\begin{tabular}{|c|c|c|c|}
\hline Characters & Path coefficient & Characters & Dath coefficiont \\
\hline $\mathrm{PH}$ & Patn coemincient & SD & Patn coemictent \\
\hline Direct effect on GY & -0.03 & Direct effect on GY & 0.35 \\
\hline Indirect effect via EIH & 0.22 & Indirect effect via $\mathrm{PH}$ & -0.02 \\
\hline Indirect effect via SD & 0.32 & Indirect effect via EIH & 0.23 \\
\hline Indirect effect via LA & 0.37 & Indirect effect via LA & 0.43 \\
\hline Total & 0.88 & Total & 0.99 \\
\hline EIH & & LA & \\
\hline Direct effect on GY & 0.23 & Direct effect on GY & -0.43 \\
\hline Indirect effect via PH & -0.02 & Indirect effect via PH & 0.02 \\
\hline Indirect effect via SD & 0.35 & Indirect effect via EIH & -0.23 \\
\hline Indirect effect via LA & 0.42 & Indirect effect via SD & -0.35 \\
\hline Total & 0.98 & Total & -0.99 \\
\hline Determination coefficient $\left(\mathrm{R}^{2}\right)$ & & & 0.98 \\
\hline K value & & & 0.05 \\
\hline Residual trait (U) & & & 0.14 \\
\hline
\end{tabular}

Table 4. The phenotypic correlation of productive components in direct and indirect effect on trait dependent main grain yield (GY).

\begin{tabular}{|c|c|c|c|}
\hline Characters & Path croficionte & Characters & Path confficiont \\
\hline NE & Patn coericlente & GME & Patn coetriclent \\
\hline Direct effect on GY & -0.51 & Direct effect on GY & 0.53 \\
\hline Indirect effect via NGE & 0.03 & Indirect effect via NE & 0.33 \\
\hline Indirect effect via GME & -0.35 & Indirect effect via NGE & 0.08 \\
\hline Indirect effect via 100GW & -0.03 & Indirect effect via $100 \mathrm{GW}$ & -0.01 \\
\hline Total & -0.86 & Total & 0.93 \\
\hline NGE & & $100 \mathrm{GW}$ & \\
\hline Direct effect on GY & 0.13 & Direct effect on GY & 0.04 \\
\hline Indirect effect via NE & -0.12 & Indirect effect via NE & 0.27 \\
\hline Indirect effect via GME & 0.30 & Indirect effect via NGE & -0.13 \\
\hline Indirect effect via $100 \mathrm{GW}$ & -0.04 & Indirect effect via GME & -0.16 \\
\hline Total & 0.27 & Total & 0.02 \\
\hline Determination coefficient $\left(\mathrm{R}^{2}\right)$ & & & 0.97 \\
\hline K value & & & 0.05 \\
\hline Residual trait (U) & & & 0.17 \\
\hline
\end{tabular}


photoassimilates intended to fill the grain of the cobs, resulting in lower yields (Guerra et al., 2019).

The influence of leaf area on grain yield may be affected by the cultivation method. It was experimentally observed that higher plant density in the area provided negative relationship of leaf area on grain yield, which can be reinforced by Mansfield and Mumm (2014). In contrast to these results, Adesoji et al. (2015) evaluated the influence of green manure on maize hybrids germplasm. They found that the leaf area showed a direct positive relationship (7.11\%) with grain yield. Therefore, the contribution of explanatory traits on a quantitative character needs to be carefully analyzed and should not be generalized to increase productivity in different planting systems.

The smallest direct effect of plant height on grain yield (0.03 ) was due to the high indirect effects of stem diameter ( $r$ $=0.32$ ) and leaf area $(r=0.37)$. However, the use of plant height as a trait for indirect selection or explanatory of grain yield is not recommended in crop system with high plant densities per hectare. As plant height is directly related to the number of ears produced per individual, larger plants allow emission of more than one ear per plant, contributing to the reduction of grain mass (Testa et al., 2016).

\section{The direct and indirect effects of productive components on} GY

Through the path analysis under multicollinearity of traits on grain yield, the coefficient of determination $(R 2=0.97)$ and the low effect of the residual variable $(U=0.17)$ indicated optimal representation of the characters NE, NGE, GME and $100 \mathrm{GW}$ on grain yield expression (Table 4).

Grain mass (GME) was the component with the highest positive direct effect $(r=0.53)$, whereas NE was of high negative direct effect $(r=-0.51)$ on grain yield. However, NGE had influence on GY only by the indirect effect via GME $(r=0.30)$, because its direct effect was smaller than the residual variable. The yield characteristics, such as NE and $\mathrm{GME}$, clarified the cause and effect relationship on GY, indicating that the lower number of ears per plant causes the higher grain mass, regardless of the number of grains.

According to Assefa et al. (2018), maize grain yield is result of the sum of the effects of traits number of ears per plant, number of beans per ear and grain mass. In addition, traits that do not make up this sum, but have a high direct and indirect effect, allows grain yield gains and may be useful in selecting traits in the maize breeding program (Begum et al., 2016).

It is noteworthy that some trait, even with direct correlation with the dependent variable, may not be the main cause of variations in the characteristic of interest, with an indirect effect being the largest contributor to the basic variable (Crevelari et al., 2018). Among the productive components, we observed that the $100 \mathrm{GW}$ presented the lowest direct effect coefficient $(r=0.04)$ in the GY. However, its major influence on corn grain yield showed indirect effect via NE ( $r$ $=0.27$ ), indicating that $100 \mathrm{GW}$ can only positively affect on grain yield, when the number of ear per area is increased. Similar results to $100 \mathrm{GW}$ were observed by Pandey et al. (2017), who verified direct effect of smaller magnitude of $100 \mathrm{GW}$ on grain yield $(r=0.0047)$. Higher numbers of grains in the ear and intraspecific competition for resources in crops with high plant density may decrease grain mass (Kopper et al., 2017; Williams, 2016). In this case, the larger amount of grains and ears per area in high densifiy planting system can compensate for the increase of corn grain yield (Testa et al., 2016).

\section{Principal component analysis (PCA)}

In the multidimensional space of the main components (Figure 1), the data matrix variance is distributed to PC1 (26\%), PC2 (24\%) and PC3 (21\%) presenting $71 \%$ of the total variation ratio (Fig 1). A useful interpretation of the PCA is that the total percentage change in data is explained by PCs (Jolliffe and Cadima, 2016). However, all components are not normally used because most variations and patterns in the data are limited to PC1 and PC2, which can be summarized in scatter plots (Lever et al., 2017). In this study, we observed in PCA that the traces fit into three grouping patterns as a function of the spacing used.

The set of variables with NGE, AF, GME, SD, CE, WUE and $100 \mathrm{GW}$ were more prominent in $95 \mathrm{~cm}$ and $80 \mathrm{~cm}$ spacing between lines (black and red polygon, respectively). While $\mathrm{PN}, \mathrm{Ci}, \mathrm{Gs}, \mathrm{E}$ and $100 \mathrm{GW}$ were the source of greatest variation in $60 \mathrm{~cm}$ spacing (blue polygon), while in $40 \mathrm{~cm}$ spacing (green polygon) GY, NE, HP and HIE are the traits most relevant in the data variation (Figure 1). The productive potential of corn crop, as well as the physiological and morphological traits, depend on the environment in which it is inserted so that the smaller or larger row spacing influences the expression of these characteristics (Greveniotis et al., 2019).

Based on the obtained results, the path analysis reflected the importance of the physiological $\left(\mathrm{P}_{\mathrm{N}}, \mathrm{CE}, \mathrm{EUA}, \mathrm{Ci}, \mathrm{Gs}\right)$, morphological (EIH, SD, LA) and productive (NE, GME) traits as main sources of cause and effect in the variation of grain yield of corn cultivated in reduced spacing. Thus, traits with high path coefficients are essential for observations in maize breeding programs to obtain high grain yield varieties (Santos et al., 2018a).

\section{Materials and methods}

\section{Plant materials and experimental design of field trials}

This work was conducted in the 2016/2017 agricultural year in Senador Guiomard, Acre, Brazil (090 50.9'S 670 26.4 'W in WGS84 datum). Maize hybrids were cultivated in reduced spaced environment and physiological, morphological and productive were evaluated. The experiment was carried out in randomized complete block design with four replications. The treatments were corn hybrids (2B655PW, AG7088PRO3 and P4285YHR) which grown with row spacing of $40 \mathrm{~cm}, 60$ $\mathrm{cm}, 80 \mathrm{~cm}, 95 \mathrm{~cm}$.

In minimum cropping system, sowing was carried manually on November 19, 2016. Fertilization was based on soil chemical characteristics. Weeds were controlled as needed for cultivation using the systemic herbicide glyphosate at a dose of $1,920 \mathrm{~g} \mathrm{ha}^{-1}$ of the active ingredient.

\section{Field methods for assessment of traits}

The sets of physiological traits analyzed were: net photosynthesis $\left(P_{N}\right)$; stomatal conductance $\left(G_{s}\right)$; intercellular concentration of $\mathrm{CO}_{2}(\mathrm{Ci})$ and leaf transpiration $(\mathrm{E})$. Water use efficiency (WUE) and carboxylation efficiency (CE) were also calculated by the relationship between assimilated $\mathrm{CO}_{2}$ and transpiration, and the assimilated $\mathrm{CO}_{2}$ with intercellular $\mathrm{CO}_{2}$, respectively, in the leaves of maize hybrids. 
Measurements of liquid photosynthesis and gas exchange were carried with IR-IRGA model LI-6400XT (Li-Cor Inc., Lincoln, USA). The evaluations took place at the VT full bloom stage, between 10:00 am and 12:00 pm on the same day, in the median region of the fully expanded and healthy leaf. The analyzes were performed in one plant for each treatment in the four blocks, totaling 48 individuals sampled. The photosynthetically active photon flux density (PPFD) was maintained at $1000 \mu \mathrm{mol} . \mathrm{m}^{-2} \cdot \mathrm{s}^{-1}$ and the reference $\mathrm{CO}_{2}$ at $380 \mu \mathrm{mol} . \mathrm{mol}^{-1}$, compatible with the ambient $\mathrm{CO}_{2}$ concentration.

At the end of the male flowering period, the morphological traits of the hybrids were evaluated in 10 plants of the useful area: plant height $(\mathrm{PH})$ and ear insertion height (EIH), stem diameter (SD), and leaf area (LA) according to Nascimento et al. (2019).

For the set of traits of the production components all ears of the useful area were harvested and subsequently extrapolated to the total number of ear per hectare (NE). Ten ears were randomly taken, multiplying the number of rows of grains by the number of grains in the row to obtain the number of grains per ear (NGE). After threshing of the ears, the grain mass per ear (GME) was determined and the 100 grain weight (100GW) was estimated with $13 \%$ humidity. Grain yield (GY) was calculated from threshing and weighing of grains from all ears harvested from the useful area corrected to $13 \%$ humidity and estimated for hectare.

\section{Path analysis}

Estimates of phenotypic correlation coefficients were split into direct and indirect effects of sets of physiological, morphological variables and yield components (explanatory trait) separately on grain yield (main trait), by means of the path analysis, as shown described by Wright (1921).

First, the phenotypic correlation matrix $X$ ' $X$ was obtained for each trait set. Then, the degree of multicollinearity of the matrix $X^{\prime} X$ of each set of trait was verified by the condition numbers (CN), which is the ratio between the highest and lowest eigenvalues of these matrices (Montgomery and Peck, 1981).

Under severe multicollinearity $(\mathrm{CN}>1000)$ for the set of physiological $(\mathrm{CN}=295421.99)$, morphological $(\mathrm{CN}=$ 777061.86) and productive $(\mathrm{CN}=66569.26)$ trait, the multicolinarity path analysis method was chosen according to Cruz and Carneiro (2006). Such method uses a constant $k$ on the main diagonal of the $X^{\prime} X$ matrix of each trait set to reduce the variance associated with the path analysis least squares estimator and to stabilize the path coefficients. Thus, the system of normal equations, $X^{\prime} X \widehat{\beta}=X^{\prime} Y$, became $\left(X^{\prime} X+k\right) \widehat{\beta}=X^{\prime} Y$, where $\widehat{\beta}$ are the direct effect estimators of the explanatory trait $X n$ over the main trait $(Y)$, and $X^{\prime} Y$ is the matrix of correlations of the explanatory variables with grain yield.

Phenotypic correlation matrices of physiological, morphological traits and production components, and other analyzes and tests related to multicollinearity and path analysis were performed with the aid of the GENES program (Cruz, 2016).

\section{Principal component analysis (PCA)}

To detect clustering and relationship between traits, principal component analysis (PCA) using the prcomp command of the R statistical software (R Core Team, 2015).

\section{Conclusion}

Liquid photosynthesis, carboxylation efficiency, water use efficiency, internal $\mathrm{CO}_{2}$ concentration and stomatal conductance of maize plants cultivated in $40 \mathrm{~cm}$ reduced spacing are the physiological traits with the highest direct and indirect relationship on corn grain yield. The ear height, stem diameter, and leaf area constitute the main morphological trait of cause and effect on the grain yield of maize plants cultivated in $40 \mathrm{~cm}$ row spacing. Ear number and grain mass become the main characteristics of direct and indirect effect on corn yield. Therefore, physiological, morphological and productive traits can provide grain yield gains via indirect selection when the crop is subjected to reduced of $40 \mathrm{~cm}$ row spacing.

\section{References}

Adesoji AG, Abubakar IU, Labe DA (2015) Character association and path coefficient analysis of maize (Zea mays L.) grown under incorporated legumes and nitrogen. J Agron. 14 (3): 158-163.

Anjum SA, Tanveer M, Ashraf U, Hussain S, Shahzad B, Khan I, Wang L (2016) Effect of progressive drought stress on growth, leaf gas exchange, and antioxidant production in two maize cultivars. Environ Sci Pollut Res. 23 (17): 1713217141.

Alves BM, Cargnelutti Filho A (2017) Linear relationships between agronomic and nutritional traits in transgenic genotypes of maize. J Cereal Sci. 76 (1): 35-41, 2017.

Assefa Y, Carter P, Hinds M, Bhalla G; Schon R, Jeschke M, Paszkiewicz S, Smith S, Ciampitti IA (2018) Analysis of long term study indicates both agronomic optimal plant density and increase maize yield per plant contributed to yield gain. Sci Rep. 8 (1): 1-11.

Begum S, Ahmed A, Omy SH, Rohman MM, Amiruzzaman M (2016) Genetic variability, character association and path analysis in maize (Zea mays L.). Bangladesh J Agril Res. 41 (1): 173-182.

Carvalho IR, Szareski VJ, Mambrin RB, Ferrari M, Pelegrin AJ, Rosa TC, Peter M, Silveira DC, Conte GG, Barbosa MH, Souza VQ (2018) Biometric models and maize genetic breeding: A review. Austral J Crop Sci. 12 (11): 1796-1805

Crevelari JA, Durães NNL, Bendia LCR, Vettorazzi JCF, Entringer GC, Ferreira Júnior JA, Pereira MG (2018) Correlations between agronomic traits and path analysis for silage production in maize hybrids. Bragantia. 77 (2): 243-252.

Cruz, C. D. (2016). Genes Software - extended and integrated with the R, Matlab and Selegen. Acta Scient. 38 (4): 547-552.

Cruz CD, Carneiro PCS (2006) Modelos biométricos aplicados ao melhoramento genético. 2 edn Viçosa: UFV, Minas Gerais, 668p.

Guerra YL, Guerra ML, Oliveira FJ, Tabosa JN, Melo Filho PA (2019) Comportamento de genótipos de milho com características promissoras para a produção de minimilho. Rev Agroneg Meio Amb. 12 (3): 855-874.

Guimarães AG, Oliveira JR, Saraiva EA, Silva AJM, Macedo LA, Costa RA, Guimarães CG, Costa MR (2019) Seleção de genótipos superiores de milho para cultivo no município de couto Magalhães-MG. Rev Bras Agrop Sust. 9 (2): 110119.

Greveniotis V, Zotis S, Sioki E, Ipsilandis C (2019) Field population density effects on field yield and morphological characteristics of maize. Agriculture. 9 (7): 1-11. 
Jolliffe IT, Cadima J (2016) Principal component analysis: a review and recent developments. Philosophical Transactions of the Royal Society A: Mathematical, Physical and Engineering Sciences. 374 (2065): 1-16.

Kopper CV, Meert L, Krenski A, Borghi WA, Oliveira Neto AM, Figueiredo AST (2017) Características agronômicas e produtividade de milho segunda safra em função da velocidade de semeadura e população de plantas. Pesq Agrop Pern. 22 (1): 1-6.

Leolato LS, Sangoi L, Durli MM, Panison F, Voss R (2017) Growth regulator and maize response to the increase in plant density. Pesq Agrop Bras. 52 (11): 997-1005.

Lever J, Krzywinski M, Altman N (2017) Principal component analysis. Nat Methods. 14 (7): 641-642.

Mansfield BD, Mumm RH (2014) Survey of plant density tolerance in US maize germplasm. Crop Sci. 54 (1): 157173.

Milander J, Jukić Ž, Mason S, Galusha T, Kmail Z (2017) Hybrid maturity influence on maize yield and yield component response to plant population in Croatia and Nebraska. Cereal Res Commun. 45 (2): 326-335.

Montgomery DC, Peck EA (1981) Introduction to linear regression analysis. New York: J. Wiley, 504p.

Nardino M, Baretta D, Carvalho IR, Follmann DN, Konflanz VA, Souza VQ, Oliveira AC, Maia LC (2016) Correlações fenotípica, genética e de ambiente entre caracteres de milho híbrido da Região Sul do Brasil. Rev Bras Biom. 34 (3): 379-394.

Nascimento LO, Ferreira JB, Martins MO, Nascimento GO, Lima AFB (2019) Effects of reduced spacing on maize productivity, $\mathrm{CO}_{2}$ assimilation and gas exchange. Afr J Agric Res. 14 (5): 226-231.

Olivoto T, Carvalho IR, Nardino M, Ferrari M, Pelegrin AJ, Szareski VJ, Demari GH, Souza VQ (2018) Caracteres morfológicos e rendimento de grãos de híbridos simples de milho em diferentes ambienteso em diferentes ambientes. Ver Cienc Agrov. 17 (4): 462-471.

Pandey Y, Vyas RP, Kumar J, Singh L, Singh HC, Yadav PC (2017) Heritability, correlation and path coefficient analysis for determining interrelationships among grain yield and related characters in maize (Zea mays L.). Int J Pure Appl Biosci. 5 (2): 595-603.

Pellizzaro EC, Albrecht LP, Krenchinski FH, Albrecht AJP, Migliavacca RA (2019) Redução no espaçamento do milho em solos de baixa altitude. Rev Cienc Agrar.42 (2): 492501.

R Core Team (2015) R: a language and environment for statistical computing. $\mathrm{R}$ Foundation for Statistical Computing, Vienna, Austria.

Reddy VR, Jabeen F (2016) Narrow sense heritability, correlation and path analysis in maize (Zea mays L.). J Anim Breed Genet. 48 (2): 120-126.
Renato NS, Sediyama GC, Silva JB, Pereira EG (2018) Modelo fotossintético para simulação da produtividade do milho em condições de temperatura e $\mathrm{CO}_{2}$ elevados. Rev Cienc Agrar. 41 (4): 211-220.

Ribeiro CB, Ramalho MAP, Prado PER (2014) Contribuição dos caracteres vegetativos e reprodutivos da planta de milho para a heterose na produção de grãos. Rev Bras Milho Sorgo. 13 (1): 59-68.

Saath KCO, Fachinello AL (2018) Crescimento da demanda mundial de alimentos e restrições do fator terra no Brasil. Rev Econ Sociol Rur. 56 (2): 195-212.

Santos WF, Vaz PCP, Haesbaert FM, Ferreira TPS, Sodré LF, Soares LB, Pereira JS (2018a) Análise de trilha em genótipos de milho no Sul do Tocantins. Tecn Cienc Agrop. 12 (3): 49-52.

Santos ALF, Mechi IA, Ribeiro LM, Ceccon G (2018b) Eficiência fotossintética e produtiva de milho safrinha em função de épocas de semeadura e populações de plantas. Rev Agric Neotr. 5 (4): 52-60.

Testa G, Reyneri A, Blandino M (2016) Maize grain yield enhancement through high plant density cultivation with different inter-row and intra-row spacings. Eur J Agron. 72 (1): 28-37.

Toebe M, Cargnelutti Filho, A (2013) Multicollinearity in path analysis of maize (Zea mays L.). J Cereal Sci. 57 (3): 453462.

Vian AL, Santi AL, Amado TJC, Cherubin MR, Simon DH, Damian JM, Bredemeier C (2016) Variabilidade espacial da produtividade de milho irrigado e sua correlação com variáveis explicativas de planta. Cienc Rur. 46 (3): 464-471.

Williams MM (2016) Relationships among phenotypic traits of sweet corn and tolerance to crowding stress. Field Crops Res. 185 (1): 45-50.

Wright S (1921) Correlation and causation. Journal of Agricultural Research, Washington, 20: 557-585.

Xu Y, Xu C, Xu S (2017) Prediction and association mapping of agronomic traits in maize using multiple omics data. Heredity. 119 (3): 174-184.

Yin S, Li P, Xu Y, Xue L, Hao D, Liu J, Yang T, Yang Z, Xu C (2018) Logistic model-based genetic analysis for kernel filling in a maize RIL population. Euphytica. 214 (5): 1-14.

You FM, Song Q, Jia G, Cheng Y, Duguid S, Booker H, Cloutier $S$ (2016) Estimation of genetic parameters and their sampling variances for quantitative traits in the type 2 modified augmented design. Crop J. 4 (2): 107-118.

Zuffo AM, Ribeiro ABM, Bruzi AT, Zambiazzi EV, Fonseca WL (2018) Correlações e análise de trilha em cultivares de soja cultivadas em diferentes densidades de plantas. Rev Ciênc Agron. 27 (1): 78-90. 